\title{
naw \\ Mechanisms of Choice in X-Chromosome Inactivation
}

\author{
Giulia Furlan ${ }^{1,2, *,+}$ and Rafael Galupa ${ }^{3, *,+}$ \\ 1 Wellcome Trust/Cancer Research UK Gurdon Institute, University of Cambridge, Tennis Court Road, \\ Cambridge CB2 1QN, UK \\ 2 Department of Genetics, University of Cambridge, Downing Street, Cambridge CB2 3EH, UK \\ 3 Developmental Biology Unit, European Molecular Biology Laboratory, 69117 Heidelberg, Germany \\ * Correspondence: gf329@cam.ac.uk (G.F.); rafael.galupa@embl.de (R.G.) \\ + These authors contributed equally to this work.
}

Citation: Furlan, G.; Galupa, R.

Mechanisms of Choice in

X-Chromosome Inactivation. Cells

2022, 11, 535. https://doi.org/

10.3390/cells11030535

Academic Editor: Andrew Keniry

Received: 17 December 2021

Accepted: 31 January 2022

Published: 3 February 2022

Corrected: 21 March 2023

Publisher's Note: MDPI stays neutral with regard to jurisdictional claims in published maps and institutional affiliations.

Copyright: (C) 2022 by the authors. Licensee MDPI, Basel, Switzerland. This article is an open access article distributed under the terms and conditions of the Creative Commons Attribution (CC BY) license (https:// creativecommons.org/licenses/by/ $4.0 /)$.

\begin{abstract}
Early in development, placental and marsupial mammals harbouring at least two $X$ chromosomes per nucleus are faced with a choice that affects the rest of their lives: which of those $X$ chromosomes to transcriptionally inactivate. This choice underlies phenotypical diversity in the composition of tissues and organs and in their response to the environment, and can determine whether an individual will be healthy or affected by an X-linked disease. Here, we review our current understanding of the process of choice during X-chromosome inactivation and its implications, focusing on the strategies evolved by different mammalian lineages and on the known and unknown molecular mechanisms and players involved.
\end{abstract}

Keywords: X-chromosome inactivation; allelic choice; skewing; placentals; marsupials

\section{X-Chromosome Inactivation: A Special Case of Dosage Compensation between the Sexes}

In several taxonomic groups of animals, including nematodes, insects and mammals, the sex of a new individual is determined by sex chromosomes. The evolution of sex chromosomes has meant that the different sexes might end up with different dosages of sex-chromosome products; in humans, this would result in twice as much dose of $\sim 1000 \mathrm{X}$-linked genes in XX individuals compared to XY individuals. While for some species these differences appear to be tolerable (reviewed in [1]), many others have evolved dosage compensation mechanisms to equalize sex-chromosome-linked gene expression between the sexes. Several strategies are known; for instance, in the fruit fly Drosophila melanogaster, hypertranscription of the $\mathrm{X}$ chromosome in $\mathrm{XY}$ individuals ensures an equal dose of $X$-linked products between $X Y$ and $X X$ individuals. In the soil nematode Caenorhabditis elegans, dosage compensation happens in XX individuals (hermaphrodites) resulting in halved expression of both $\mathrm{X}$-chromosomes, hence reducing global $\mathrm{X}$-linked gene expression to the levels of the single $X$ chromosome of $X O$ individuals (males). In most mammals studied, dosage compensation also happens in XX individuals, but instead occurs via the transcriptional silencing of one of the $\mathrm{X}$ chromosomes, a process known as $\mathrm{X}$-chromosome inactivation (XCI) (or "lyonisation", after geneticist Mary Lyon, who first proposed such mechanism to occur [2]). Contrary to X-hypertranscription in XY flies or transcriptional repression of both $\mathrm{X}$ chromosomes in nematodes, $\mathrm{XCI}$ in $\mathrm{XX}$ mammals involves the differential treatment of two homologous chromosomes sharing the same nucleoplasm. While one $\mathrm{X}$ chromosome needs to remain transcriptionally active, the other must be (almost) completely shut down. In this review, we discuss our current understanding of how this choice is made across different mammalian taxa, and the molecular players underlying different strategies to achieve it. 


\section{Types of XCI Choice across Mammals: Predetermined or Rolling Dice}

Different mammals have developed distinct strategies to accomplish X-linked dosage compensation. In extant prototherian mammals (monotremes, the egg-laying mammals), which possess multiple sex-chromosomes, chromosome-wide X-inactivation is absent, and dosage-compensation occurs in a locus- and tissue-specific manner [3]. In therian mammals, including the marsupial and placental clades, dosage compensation for $\mathrm{X}$-linked gene products is achieved by nearly fully silencing one of the two X chromosomes in XX individuals. The need for this selective silencing brings about the problem of "choice": how do these mammals choose which one of the two Xs to inactivate? While some species have solved this problem by always selecting the same $X$, for other species the process seems to be resolved rather randomly (Figure 1).

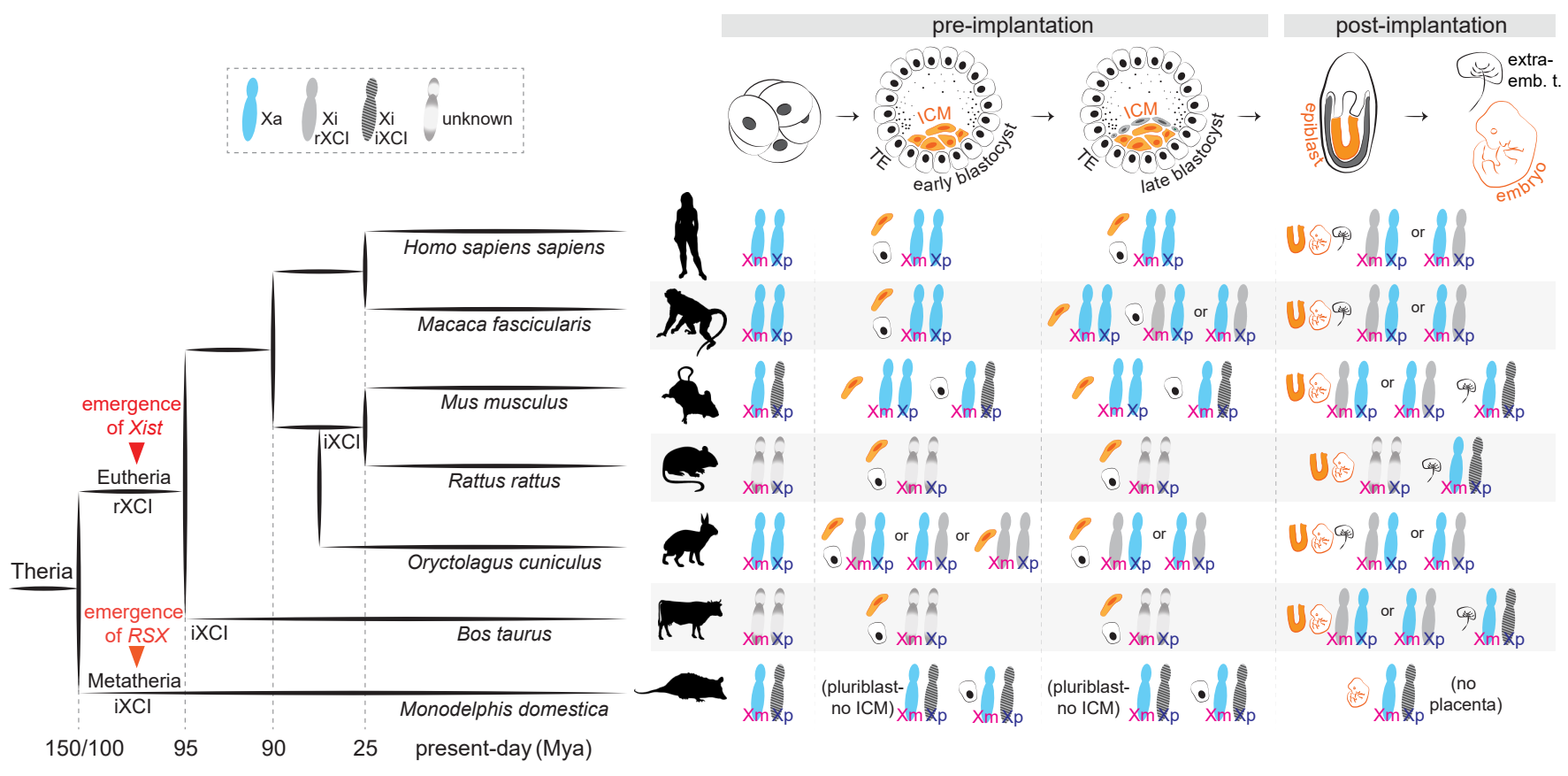

Figure 1. X-chromosome inactivation across species. Left: a phylogenetic tree indicating the evolution of random and imprinted XCI and the emergence of long non-coding RNAs Xist and RSX in Theria. Right: X-chromosome inactivation dynamics across development in representative species.

In marsupials (metatherians), the paternal X chromosome is exclusively (100\%) chosen for inactivation [4], in a process known as "imprinted" X-chromosome inactivation (iXCI). The situation is more diverse in placental mammals (eutherians): iXCI occurs only in specific species and developmental stages and/or tissues, and the prevalent form is "random" $\mathrm{X}$ chromosome inactivation (rXCI), observed in adult somatic tissues [5]. During rXCI, and in the absence of "skewing" influences, both the paternal X $(\mathrm{Xp})$ and the maternal X $(\mathrm{Xm})$ have roughly the same $(\sim 50 \%)$ chance of being inactivated.

In the murine preimplantation embryo, the most well-studied model for XCI research, a first wave of XCI following zygotic genome activation results in the exclusive inactivation of the $X p$ (Figure 1). At the late blastocyst stage, inactivation of the $X p$ is maintained in the extra-embryonic lineages, but reversed in the cells that will give rise to the embryo proper, which subsequently undergo random XCI upon implantation [6-12]. Imprinted $\mathrm{XCI}$ is also observed in the extra-embryonic cell lineages of rats [13] and cows [14,15]. In humans, early studies in trophoblast cells argued that the Xp is preferentially inactivated in this extra-embryonic tissue [16,17]; however, subsequent allele-specific analyses have concluded that XCI is in fact random in the placenta as well [18], with possibly only a slight bias towards the $\mathrm{Xp}$ [19]. Likewise, random XCI seems to be the only form of $X$ 
inactivation in rabbits [20], pigs [21,22] and cynomolgus monkeys [23], both in embryonic and extra-embryonic cell types.

At the molecular level, imprinted and random XCI share some mechanistic features: both are regulated by a region on the $\mathrm{X}$ chromosome named the " $\mathrm{X}$-inactivation centre", $X i c$ (though non-homologous between marsupials and placental mammals) and both are associated with the action of long non-coding RNAs (lncRNAs) that coat the $X$ chromosome in cis and are proposed to direct gene silencing-for a recent review see [24]. In placental mammals, the lncRNA Xist is considered the critical trigger of XCI: this has been shown genetically in mice for both imprinted and random forms [25-27]. In marsupials Xist is not conserved, but a lncRNA with Xist-like properties, $R s x$, has been recently identified in the gray short-tailed opossum: Rs $x$ is expressed from and accumulates on the inactive $\mathrm{X}$ in $\mathrm{XX}$ cells and is able to silence genes in cis when transgenically inserted in mouse embryonic stem cells [28]. Accordingly, a recent methylome study in koalas found that the DNA methylation landscape upstream of Rsx showed a XX-specific pattern [29], consistent with another study in the opossum [30], altogether raising the possibility of Rsx being the functional analog of eutherian Xist.

\section{Mechanisms of iXCI: Choosing to Inactivate the $\mathrm{Xp}$}

At the molecular level, imprinted XCI implies the existence of an epigenetic difference between $\mathrm{Xp}$ and $\mathrm{Xm}$ that would fully bias the choice towards the paternal chromosome. Rastan and colleagues, using uniparental embryos, showed that Xist expression is initially dictated solely by parental imprinting: paternal alleles are expressed and maternal alleles remain repressed, irrespective of $X$ chromosome number [31]. The imprint could be in theory carried by the $\mathrm{Xp}$, in a way that would promote $\mathrm{XCI}$ in cis, or by the $\mathrm{Xm}$, in a way that would prevent $\mathrm{XCI}$ in cis. In marsupials, the molecular underpinnings of the imprint remain unknown, but a lot more has been investigated in the mouse, given its imprinted form of XCI during preimplantation development. Over the years, several hypotheses have been postulated regarding the nature of the imprint and the molecular mechanisms that lead to the inactivation of the Xp (Figure 2).

\subsection{The First Proposals: A Paternal Imprint}

Early studies postulated that the paternal $\mathrm{X}$ chromosome is intrinsically prone to inactivation, perhaps due to different levels of DNA methylation [32-35] or DNA condensation at the time of fertilization (reviewed in [36]). More recently, another hypothesis suggested that the Xp could retain an epigenetic memory acquired during its life cycle in the male: in both eutherians and metatherians, the imperfect pairing of the $X$ chromosome with the $Y$ chromosome during male gametogenesis results in the inactivation of both sex chromosomes during the pachytene stage of meiosis, in a process called meiotic sex chromosome inactivation (MSCI) [37,38]. According to this hypothesis, the Xp retained the epigenetic memory of MSCI silencing and entered fertilization in a pre-inactivated state $[9,27,39]$. However, it was later shown that the $\mathrm{Xp}$, like the autosomes, is transcribed right after fertilization, at the time of zygotic genome activation, and only then is silencing initiated [27,40-42]. Moreover, Heard and colleagues showed that paternally inherited Xist transgenes that do not undergo MSCI are capable of inducing cis-inactivation [41], suggesting that MSCI is not necessary for iXCI in mice. Hence, the Xp is not inherited in a "pre-inactivated" state. This does not, however, answer the question of which parental $X$ harbours the molecular imprint that leads to Xist expression from the Xp during early development. 


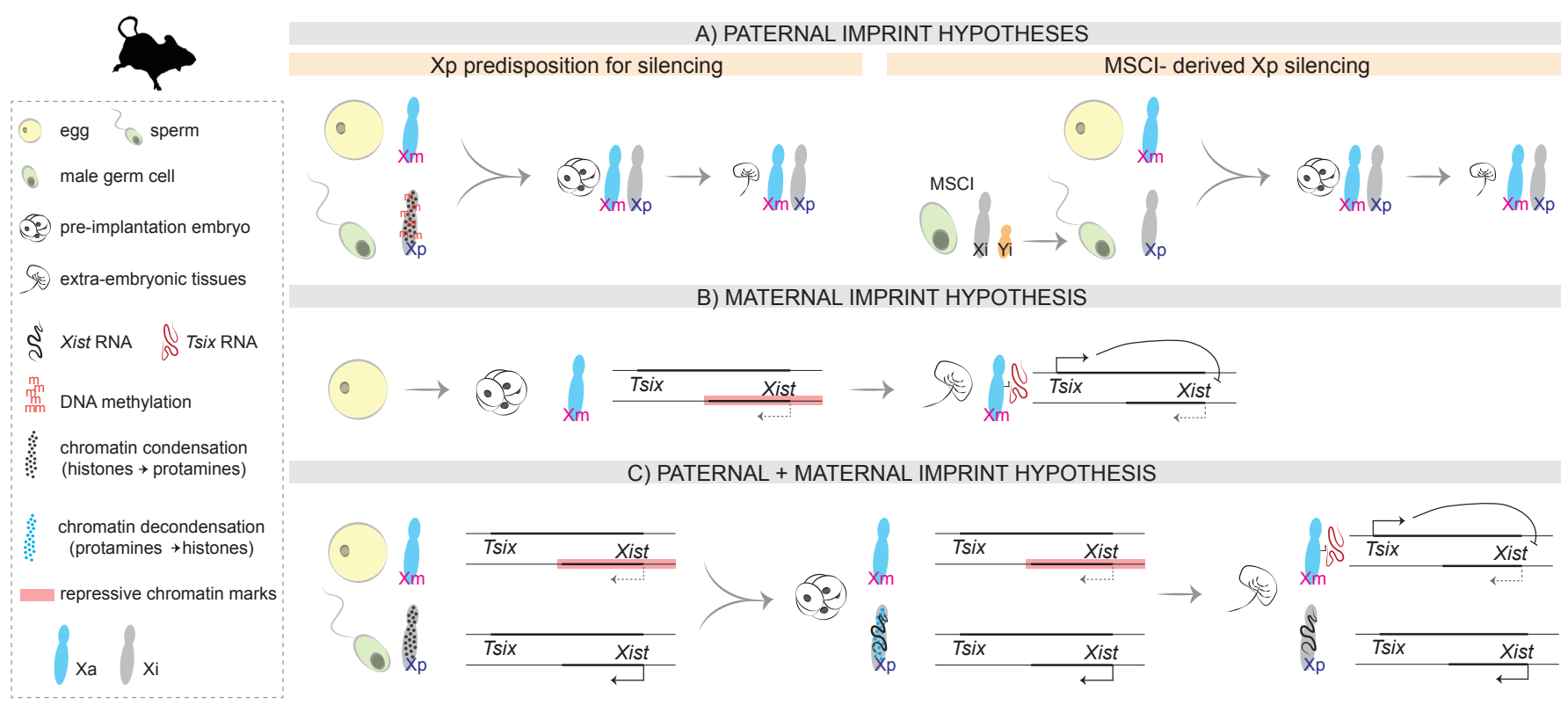

Figure 2. Hypotheses on the molecular nature of the imprint in mice. (A) Paternal imprint: The Xp inherits a predisposition for silencing from its life cycle in the male. (B) Maternal imprint: In the preimplantation embryo, repressive chromatin marks on the $\mathrm{Xm}$ (including the Xist promoter region) prevent Xist expression on the $\mathrm{Xm}$. In the extra-embryonic tissues of the post-implantation embryo, Tsix expression prevents Xist upregulation in cis. (C) Paternal and maternal imprint: A combination of both hypotheses, considering the different chromatin condensation states of the Xp in the sperm and in the paternal pronucleus after fertilization.

The persistence of MSCI as a means of dosage compensation was postulated in metatherians and thought to explain how XCI was possible in the absence of a Xist homolog [43-46]. However, the observation that X-linked genes silenced by MSCI are reactivated after meiosis and subsequently re-inactivated in the female [47], refuted this hypothesis. As previously mentioned, an Xist analog was later found in marsupials, the lncRNA Rsx [28], but the molecular nature of the imprint in this clade remains unknown.

\subsection{The Unexpected Outcome: A Non-Canonical Maternal Imprint}

Imprinted XCI in mice has also been postulated to rely on a maternal imprint [31,48], later shown to be established in the female germ line and to prevent the Xm from being silenced during early embryogenesis [49]. In agreement with the "maternal imprint" hypothesis, studies on mouse embryos carrying extranumerary $\mathrm{X}$ chromosomes showed that they died early in development only when the extra chromosome was the maternal $X$ [50-52], presumably due to failure of either Xm to inactivate (and ensuing lack of dosage compensation). Interestingly, this contrasts with the case of humans: $\mathrm{XmXmY}$ (Klinefelter syndrome) and $\mathrm{XmXmXp}$ (triple-X syndrome) individuals are viable, consistent with the lack of imprinted XCI in our species.

Importantly, the maternal imprint in mice is lost at the morula stage, during preimplantation development, as observed in uniparental embryos [31], and suggested by studies on diploid parthenogenetic embryos, which have two Xm chromosomes (no Xp)-in these embryos, inactivation of one of the $\mathrm{Xm}$ eventually occurs, both in the embryo proper and the extra-embryonic tissues [53,54].

Recently, a large-scale nuclear transfer study using donor cells from different stages of gametogenesis and embryogenesis showed that paternal $\mathrm{X}$ chromosomes always underwent inactivation during the time-window of imprinted $\mathrm{XCI}$, and maternal $\mathrm{X}$ chromosomes unless derived from fully grown oocytes [55]. This confirmed that a maternal imprint is established late in oogenesis, and erased in embryonic but also extraembryonic lineages, 
where an imprinted XCI pattern persists. The loss of the imprint during preimplantation development suggests that other mechanisms might underlie iXCI in the extraembryonic lineages, which are being specified around the time the imprint is lost.

Canonical genomic imprinting relies on allele-specific DNA methylation (see [56] for a recent review), and such mechanism was initially proposed to underlie iXCI as well [33-35]. Contrary to these early hypotheses, however, later studies with DNA methyltransferase maternal knockout embryos ruled out DNA methylation as having a role in setting the imprint [57]. Recently, Yi Zhang's lab identified the polycomb-repressive complex 2 (PRC2)-dependent mark, H3K27me3, as a DNA methylation-independent mechanism underlying the imprinted patterns of several loci across the genome [58], including the Xist locus [59]. In particular, a large H3K27me3 domain was found to coat the Xist locus during oocyte growth and to persist through preimplantation development, with loss of maternal H3K27me3 resulting in ectopic Xist expression from the $\mathrm{Xm}$ and maternal $\mathrm{XCI}$ in preimplantation embryos [59]. Interestingly, this H3K27me3 domain at Xist and at other maternally-imprinted loci coincides with maternally-specific topological domains in early embryos as detected by $\mathrm{Hi}-\mathrm{C}$, a chromosome conformation capture technique [60]. Of note, another repressive histone mark, $\mathrm{H} 3 \mathrm{~K} 9 \mathrm{me} 3$, has been shown to be enriched at the Xist locus in early preimplantation embryos [61] but its role remains contested: while overexpression of $K d m 4 b$, a H3K9me3 demethylase, partially derepresses Xist on the $\mathrm{Xm}$ in parthenogenetic embryos [61], injection of $K d m 4 b$ mRNA into in vitro fertilization-derived biparental embryos does not result in Xist derepression on the Xm in either XY or XX embryos [59].

While the chemical nature of the imprint has finally been discovered, it is still not clear which sequences are critical to carry the imprint and/or for the imprint mark to be laid. The maternal H3K27me3 domain spans $\sim 450 \mathrm{~kb}$, including the Xist locus and its positive regulators Jpx and Ftx $[62,63]$. The critical sequences are most likely contained within a subregion of that domain, given that a $210 \mathrm{~kb}$ transgene that contains Xist, Jpx, and part of Ftx, as well as Xist's negative antisense regulator Tsix [64], can recapitulate the imprinted expression of Xist in early mouse development [41]. Tsix-which is not covered by the H3K27me3 domain-was initially implicated as the imprinted locus, given that disruption of Tsix on the Xm leads to Xist upregulation in cis and results in post-implantation death in females due to impaired development of extraembryonic lineages $[65,66]$. However, at the 4-cell stage, when Xist starts to be upregulated on the Xp, Tsix is still silent on the Xm [66], suggesting that the maternal imprint is independent of Tsix transcription-which seems to be important at later stages, in the extraembryonic lineages, to maintain the imprinted pattern of XCI.

Regarding Ftx and Jpx, deletions of either alone show that they are dispensable for iXCI in preimplantation embryos [60,67]. However, maternal transmission of a $\sim 115 \mathrm{~kb}$ deletion that spans the Jpx locus, part of the Ftx locus, and the intergenic region in between them led to compromised viability of XX embryos and no XY pups being born [60], a pattern compatible with loss of the maternal imprint. It remains to be investigated how exactly such sequences contribute to the imprinted expression of Xist, if important for the establishment of the imprint (H3K27me3 deposition) during oogenesis, or for its maintenance, and whether other regions might be necessary as well to carry the imprint (e.g., the Xist promoter).

In marsupials, whether the Rs $x$ locus carries an imprint on either the $\mathrm{Xp}$ or the Xm or both is not fully known, but a non-coding RNA antisense to Rs $x$ and Xsr, has been recently discovered and shown to exhibit a Tsix-like behavior [68]. Xsr is expressed from the Xm in the early embryo, but not in adults, and is thought to prevent Rsx expression in cis [68]. Early Xsr expression from the $\mathrm{Xm}$ could, in marsupials, play an imprint role equivalent to Tsix during the maintenance phase of $\mathrm{XCI}$ in murine extraembryonic tissues.

Overall, a rather complex picture emerges, which favors the existence of a maternal imprint, at least in mice: during oogenesis and in the pre-implantation embryo, chromatin condensation and the deposition of repressive histone marks at the Xist promoter are 
associated with preventing Xist expression on the $\mathrm{Xm}$. Later, in the extra-embryonic tissues of the post-implantation embryo, Tsix expression from the $\mathrm{Xm}$ prevents its silencing in cis by repressing Xist expression.

It is still possible, however, that the imprint is not carried by the Xm exclusively, but that a combination of maternal and paternal signals is needed to ensure monoallelic Xist upregulation on the $\mathrm{Xp}$. For instance, chromatin structure at the Xist locus differs between the paternal and the maternal chromosomes at the time of fertilization: not only the maternal $X$ carries repressive chromatin marks, but the paternal $X$ undergoes chromatin decondensation when the sperm-derived genome of the paternal pronucleus is subjected to global replacement of protamines with histones [69]. Hence, it is possible that some loci, including Xist, are poised to be preferentially transcribed over their maternal counterparts in the zygote. Moreover, since silencing of repeats (LINEs, SINEs) is proposed to precede genic silencing in iXCI [27], it is also possible that the Xp is treated differently according to its epigenomic content, with repeat-rich regions being inherited in a pre-inactivated state through the paternal germline following MSCI $[9,70]$ and gene-rich regions being inactivated de novo after ZGA. Interestingly, this could also be true for marsupials, where cot1 repeats are silenced during the final stages of spermatogenesis and are possibly inherited in a pre-inactivated state $[47,71]$.

\subsection{Evolutionary Considerations about $\mathrm{XXCI}$}

Imprinted XCI was initially hypothesized to represent the ancestral form of X inactivation in therian mammals, potentially present in the common ancestor between marsupials and placentals, which diverged 180 million years ago [39,72]. Imprinted XCI was initially thought to be partially conserved in mice, which also evolved random XCI, but lost in hominids, who evolved random XCI exclusively-reviewed in [73]. However, as it becomes clearer that the molecular players involved in marsupial iXCI and murine iXCI are different and not homologous, it seems more plausible that iXCI evolved independently (and convergently) in the phylogenetic lineages of mammals with pouches and mammals with placentas; the common ancestor had perhaps no X-linked dosage compensation mechanism, like monotremes.

The absence of imprinted Xist expression in non-rodent eutherian species, which in general have a later onset of XCI in early development, has been suggested to be linked to the fact that embryos of those species undergo several rounds of DNA replication before Xist starts to be expressed; this way, parent-specific chromatin structure differences would possibly be erased, resulting in the two Xist alleles being epigenetically identical [74,75]. A more recent model posits that an imprint that instructs strictly monoallelic XCI must exist in species with early XCI initiation (such as marsupials and mice) to prevent the possibility of inactivating both $X$ chromosomes [68], which, nevertheless, happens during random XCI (discussed below). In early development the consequences of having two silent Xs (such as cell death) would be very detrimental to the developing embryo, contrary to later development, when more cells are present and the embryo could potentially afford to lose some [68]. Also, during random XCI, in post-implantation development, inactivation of both Xs can be reversed [76]. During iXCI such reversion would probably be difficult to trigger, given the fast paced kinetics of preimplantation development.

Albeit intriguing, these hypotheses do not explain why, in both marsupials and mice, it is always the paternal $\mathrm{X}$ but never the maternal $\mathrm{X}$ chosen for inactivation. A proposal by Heard and colleagues states that a maternal imprint is needed "to prevent the early activity of $X$-linked paternal genes involved in placental growth, as proposed in the parental conflict theory, particularly in rodents where zygotic gene activation occurs very early on in development" [41]. Interestingly, however, life is possible even if it is the Xp that remains active: XX mice with a paternally-inherited Xist deletion die during embryogenesis due to XCI failure in the extra-embryonic tissues $[49,77]$, but this lethality can be rescued by deleting Tsix on the Xm, which then undergoes inactivation [66]. While this indicates that inactivating the $\mathrm{Xm}$ instead (and keeping the Xp active) can sustain life, it also suggests that 
the strength of the imprint is such that it is very difficult to override it. It is still unknown whether there would be decreased fitness due to inactivating the $\mathrm{Xm}$ in $\mathrm{XX}$ individuals.

On the other hand, had the opposite pattern of iXCI evolved in XX embryos-always inactivating the $\mathrm{Xm}$-then mechanisms would have had to evolve in XY embryos to make sure that their $\mathrm{Xm}$ would always remain active during development. It is thus possible that a strong maternal imprint preventing early inactivation of the Xm evolved to limit the risk of XY offspring inheriting a pre-inactivated $\mathrm{Xm}$, a condition that would be lethal during early development.

\section{Mechanisms of rXCI in Mouse: A Race for Inactivation}

In the context of $\mathrm{iXCI}$, it is intuitive to think about choice: given its parental origin, each chromosome has its fate predetermined. When talking about rXCI, we usually pose the question of choice in similar terms: how is one of the $X$ chromosomes chosen at random to upregulate Xist thus becoming the inactive $\mathrm{X}$ chromosome? However, this is misleading. Contrary to what happens during $\mathrm{iXCI}$, in which choice precedes Xist expression and gene silencing, choice during rXCI is only "set" after Xist is upregulated and starts inducing (some) gene silencing in cis, which then prevents the other chromosome from doing the same (Figure 3). Thus, it is the beginning of the XCI process itself that determines choicechoice is not set from the start. Accordingly, we now know that both $\mathrm{X}$ chromosomes can start upregulating Xist: this has been observed both in the early mouse embryo and in cultured mouse embryonic stem cells undergoing differentiation [76]. This situation can be reversed [76], otherwise cells would die, and thus, the process resets and each chromosome has another opportunity to become the inactive X. Biallelic Xist expression is also observed in rabbits, monkeys and human embryos $[20,23,78,79]$, but much less is known in these species about the regulation of Xist expression and the onset of XCI. These observations serve to illustrate how, preceding the stages in which random XCI is set, both chromosomes presumably have the potential to become the inactive X. Alternatively, one could imagine a scenario similar to what happens during iXCI: prior to the initiation of rXCI, one of the chromosomes would be "marked" at random to become the chosen one for inactivation. This chromosome would then upregulate Xist, which would lead to transcriptional silencing in cis. However, no such mark has been discovered-apart from the upregulation of Xist itself, which could be an indicator of which chromosome would be the inactive $X$ (though not in $100 \%$ of the cases, as discussed above). This and other alternative scenarios have been thoroughly and elegantly reviewed in Mutzel and Schulz's "systems biology perspective" on rXCI [80]. The model that reflects our current understanding of the process is that the "random" choice we observe in the tissues of XX mammals is a final result of which chromosome managed to start inactivating first while efficiently preventing the other chromosome from starting its own inactivation. The Schulz lab has recently established a theoretical framework (accompanied by experimental demonstrations) by which to think about the problem of random XCI [76]; this framework explains not only the process of choice, but also the process of counting, as well as observations of XCI patterns from cells with different numbers of $X$ chromosomes and across species.

In the absence of a choice mechanism before the upregulation of Xist during random XCI, the question of choice-which $X$ chromosome ultimately becomes the inactive $X$-morphs into two separate questions: what influences the upregulation of Xist from one chromosome or the other, and what mechanisms prevent one chromosome from upregulating Xist when the other one started doing so. 
\begin{tabular}{l|l} 
1. pre- $\mathrm{XCl}$ & 2. Xist upregulation
\end{tabular}
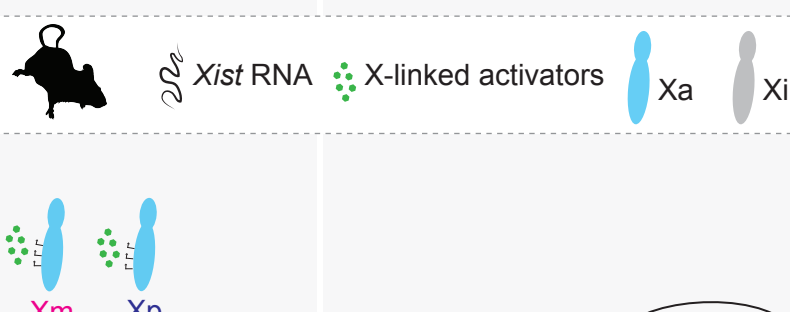

Xm Xp

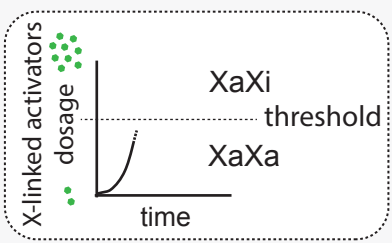

$\Delta$

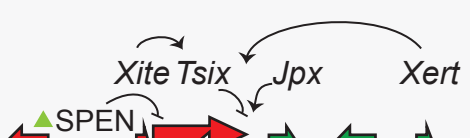

Xert

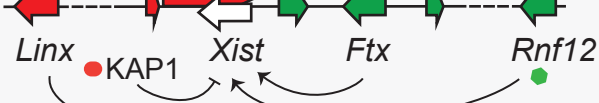

3. feedback

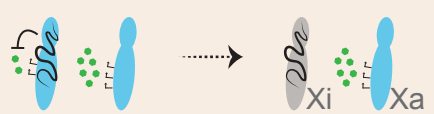

$\mathrm{Xm}$ or Xp Xp or Xm

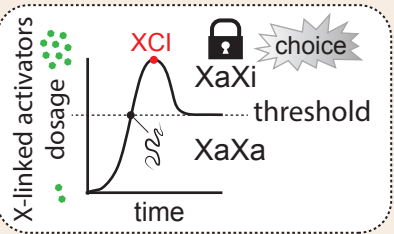

time
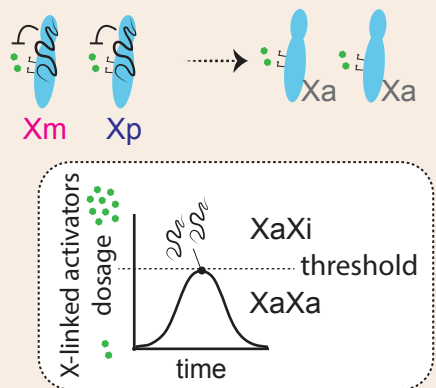

Figure 3. Dynamic model of choice during random XCI. Left: Pre-XCI status. Both X chromosomes are active and transcribe $X$-linked genes. The dose of X-linked activators increases towards the threshold necessary for productive Xist upregulation. Middle: Biallelic X-chromosome transcription allows the cell to reach the threshold for Xist activation. X-linked and autosomal cis and trans positive and negative regulators influence the initiation of Xist upregulation, which can occur on a single $X$ chromosome or on both. Only factors and loci discussed in the text have been included in the figure. Right (top): In cells that have upregulated Xist monoallelically, X-wide cis-silencing triggered by Xist RNA causes a drop in the level of activators, preventing the second chromosome from upregulating Xist. Choice is locked-in. Monoallelic Xist expression (and cis-silencing) has to be sustained, either through enough dosage of activators and/or feedback mechanisms. Right (bottom): In cells that have upregulated Xist biallelically, excess Xist expression triggers rapid downregulation of X-linked activators on both $X$ chromosomes, and this drop in levels below the threshold causes Xist expression to switch off. Both $\mathrm{X}$ chromosomes remain active and the process must start again.

\subsection{Influencing Choice by Influencing Xist Upregulation}

What do we know about how Xist might become upregulated asymmetrically? Both cis and trans mechanisms could be at play; cis-mechanisms by acting independently on each chromosome, and trans-mechanisms by underlying local (chromosomal) fluctuations (e.g., trans-factors concentrations) could affect chromosomes differentially. Certain trans-acting factors have been proposed to bind asymmetrically to the Xist promoter: YY1, RIF1 and KAP1. At the onset of XCI, RIF1 is associated with the X chromosome upregulating Xist and is critical for upregulation [81]. A very similar role has been proposed for YY1 [82], and KAP1 binds to the allele with no Xist expression, due to the absence of RIF1 [81]. The asymmetric binding of RIF1 (and KAP1) seems to be downstream of fluctuations of antisense transcription across the Xist locus [81], while YY1 binding is due to differential DNA methylation of Xist alleles at the onset of XCI [82]. This has also been reported downstream of antisense transcription across the Xist locus [83-85]. Together, these findings suggest that the asymmetric binding of these trans-factors serve as "bookmarks" for the future active and inactive $X$ (though most likely not irreversibly), reinforcing asymmetries derived from cis-acting mechanisms.

Several loci are known to influence the regulation of Xist in cis, however, this is mainly based on knockout studies-i.e., we understand the consequences for XCI choice of the 
absence of such loci, but how they potentially regulate Xist asymmetrically when their two copies are present remains speculative. One such cis-acting loci is Xist's antisense transcription unit, Tsix. Heterozygous deletions of its promoter region lead to nonrandom $X C I$ patterns such that the mutant $X$ chromosome is always the inactive $X[64,86]$. Thus, it seems that the absence of Tsix substantially increases the likelihood of Xist upregulation from the same chromosome, in such a way that it is always the mutant chromosome that upregulates Xist and becomes the future $\mathrm{Xi}$-the other allele never has a chance to do it. One would expect Tsix-heterozygous cells to be quicker than wild type cells at upregulating Xist and initiating XCI; faster kinetics during differentiation have indeed been observed $[87,88]$. Additionally, one can conclude that Tsix normally represses Xist expression in cis, and further studies demonstrated that it is Tsix transcription (and not its RNA products) that is important for negative regulation $[83,89,90]$. The exact mechanisms seem to involve chromatin changes at the Xist promoter when Tsix is transcribed across it $[83,84,91-94]$ and potentially transcription interference via polymerase clashes [76]. What are the implications for the initiation of XCI when both Tsix alleles are functional? Given that Tsix transcription seems to affect the likelihood of Xist expression in cis, asymmetries in Tsix transcription between the two $X$ chromosomes could therefore generate asymmetries in $X i s t$ upregulation and therefore ultimately influence which $\mathrm{X}$ becomes inactive. However, we do not knowwhether, for instance, rates of Tsix transcription could modulate the probability of Xist to be upregulated-and if such a relationship would be linear or nonlinear. Overexpression of Tsix from one allele exclusively has the expected effect of that chromosome remaining active [91]. However, no experiments have been done in which Tsix transcription is modulated and Xist expression followed at the single-cell, singlechromosome level. Importantly, while Tsix function is critical in mice, the locus is not well conserved across placental mammals; in humans, the locus is predicted to be present but its structure is different (it does not overlap with the entire Xist locus and promoter), raising questions of whether TSIX is at all functional [95-97].

While manipulations of Tsix seem to have an all-or-nothing effect regarding choice, other loci in the vicinity of Xist have milder but significant effects on choice patterns. Heterozygous deletions of Xite (an enhancer-like locus upstream of Tsix) or of the promoter of Linx (another lncRNA locus within the X-inactivation centre) lead to skewed patterns of choice, with the mutant chromosome being more often the inactive $X[98,99]$. These loci thus seem to be negative cis-regulators of Xist; Xite is thought to act via influencing Tsix transcription and the promoter of Linx acts on Xist independently of Tsix and presumably via a "silencer" (a "negative" enhancer) type of mechanism (and not via Linx transcription or transcripts). In each case, asymmetries in Xite or Linx function between the chromosomes could lead to asymmetries in terms of Xist upregulation during development and differentiation, though presumably with less influence than Tsix, as judged by the results of the knockout studies. Like Tsix, Xite is poorly conserved across placental mammals [97], while the promoter of Linx is well conserved, suggesting a more ancestral role as a cis-negative regulator [99]. Another mouse-specific locus known to influence choice is the Xce, which we discuss in a section below.

Interestingly, the three negative regulators of Xist-Tsix, Xite and Linx-all reside within the same topologically associating domain (TAD). TADs partition the mammalian genome in regions that include genes and cis-regulatory elements showing functional similarities, and such partitioning seems to be critical, at least for some developmentally-regulated loci-for a recent review, please see [100]. The Xist/Tsix unit-in mice and humans-lies at the boundary between two TADs [97,101,102], with each promoter associated with opposite, neighbouring TADs-as mentioned, the Tsix promoter lies within the same TAD as Xite and Linx, and the Xist promoter shares a TAD with loci such as Jpx, Ftx, Xert and Rnf12, which all have shown to be positive regulators of Xist. Genetic manipulations that invert the Xist/Tsix locus, changing the TADs in which the promoters are placed, lead to the misregulation of both Xist and Tsix and effects on XCI [103], highlighting how the cis-regulatory landscape of each promoter is critical for appropriate initiation of XCI. 
Among the positive regulators of Xist within the same TAD as the Xist promoter, three lncRNA loci have been reported to influence Xist expression in cis and could therefore affect choice-Ftx and Xert via their transcription [62,104], and Jpx transcriptionally or posttranscriptionally $[63,105]$. Jpx has also been reported as a trans-acting regulator of Xist via its lncRNA [106]. A recent study has identified a series of proximal and distal enhancers that are also required for activation of Xist upregulation in cis [104]. Elements within the Xist locus itself have also been reported to contribute to Xist upregulation-e.g., [107], including an antisense transcript, XistAR [108].

In conclusion, loci that influence the upregulation of Xist can ultimately influence choice: the $\mathrm{X}$ chromosome that upregulates Xist first is more likely to become the $\mathrm{Xi}$. Importantly, a cis-acting positive feedback mechanism has been predicted to be essential for establishing Xist monoallelic regulation during the initiation of XCI, and therefore critical for choice $[76,80]$. This cis-acting positive feedback mechanism reinforces Xist expression, either via mutual repression (Xist expression silences one of its cis-repressors) or mutual activation (Xist expression promotes expression of its cis-activators). Mutual repression is known to exist between Xist and Tsix: silencing of Tsix expression by Xist RNA alleviates Tsix-mediated repression of Xist expression. Recently, the protein SPEN, shown to be essential for gene silencing during XCI [109], has been implicated in this feedback mechanism: SPEN (recruited by Xist RNA) is required to silence the Tsix promoter, which in turn is required for consistent Xist upregulation [110].

\subsection{Influencing Choice by Preventing Xist Upregulation from the Second Chromosome}

Choice during random XCI does not depend exclusively on which X upregulates Xist first. This must be sustained on that chromosome, and the other $X$ has to be prevented from upregulating Xist as well, only then is choice really established. How does this work at the molecular level? X-linked factors need to be present in a double dose to activate Xist-this model explains not only the process of choice but also why XCI happens in XX individuals but not in XY individuals, which never have a double dose of such $X$-linked factors. When one of the chromosomes upregulates Xist, its RNA induces silencing of genes in cis, including those coding for the X-linked activators, and their dose in the cell is reduced to half, which is not enough for the other chromosome to be able to upregulate Xist efficiently [111,112]. Hence, the fate of each chromosome becomes locked, as one becomes the $\mathrm{Xi}$, and the other remains active- "choice" is thus determined, but only then. In cells in which both chromosomes upregulate Xist, the same model predicts that cissilencing leads to a quick drop in the levels of X-linked activators, needed to sustain Xist upregulation. Therefore, Xist expression from both chromosomes aborts and the process starts again $[76,112]$.

One such dosage-dependent X-linked activators is encoded by the Rnf12/Rlim locus: RNF12 is a ubiquitin ligase that targets for degradation of the pluripotency factor REX1, a repressor of Xist that binds to its promoter in undifferentiated cells [113-115]. In XY murine embryonic stem cells, extra copies of Rnf12 can activate Xist expression, while in XX murine embryonic stem cells, knockout of Rnf12 seems to abolish XCI during differentiation [113], although these latter results have been contested [116]. In vivo, Rnf12 knockout is reported to prevent imprinted XCI but not the random form [116,117]; however, the inducible system used for knocking out Rnf12 and study rXCI might not be the most suitable in terms of developmental timings [118], therefore, Rnf12's role in rXCI remains open. We know, nevertheless, that there is more to the dosage-dependent regulation of XCI than Rnf12. For instance, in XX murine embryonic stem cells with a single copy of Rnf12 (heterozygous deletion), XCI is not abolished, but only delayed [113], suggesting that there are other factors capable of activating XCI in a dosage-dependent manner [80]. The other known X-linked activators of Xist and XCI (such as Jpx and Ftx) cannot account for the feedback loop necessary to prevent the upregulation of Xist from one chromosome when the other has already started it [80], therefore additional factors remain to be identified. 


\section{Choice in Human rXCI: Biallelic Dampening or Direct Monoallelic Inactivation?}

$\mathrm{X}$ chromosome activity has specific dynamics in humans: like in the mouse, both $X s$ are transiently active in the inner cell mass of the blastocyst of the preimplantation XX embryo [20,78,119], but, surprisingly, at this developmental stage, XIST is expressed from both X chromosomes [20,78,79]. Indeed, the XIST RNA accumulates in cis forming a (typical) "cloud" as observed by RNA FISH [20,78], albeit without triggering H3K27me3 enrichment [20]. Curiously, the X chromosome in XY embryos also expresses XIST and shows cis-accumulation [20]. Together, these observations were taken to strongly suggest that XIST expression is uncoupled from XCI in human preimplantation development. A similar picture has emerged for another primate, the cynomolgus monkey, in terms of XIST expression in $\mathrm{XX}$ and $\mathrm{XY}$ embryos, as reported very recently in an unprecedented study characterizing XCI dynamics during development in a non-rodent species [23]. Choice thus seems to be preceded by XIST expression, like in the mouse, but in both human and cynomolgus monkeys it seems to be more about from which $X$ to repress XIST expression.

Two models have been proposed to describe the initiation of dosage compensation in the human preimplantation embryo: $\mathrm{X}$-dampening and direct $\mathrm{X}$-inactivation-and similar considerations could be drawn for the cynomolgus monkey, see $[23,120]$. According to the dampening model, progressive increase in biallelic XIST expression results in a gradual biallelic downregulation of X-linked genes from morula to blastocyst [78], in a form of dosage compensation reminiscent of the strategy adopted by C. elegans hermaphrodites and comparable to an "absence of choice". How this Xd/Xd state would later transition into an $\mathrm{Xa} / \mathrm{Xi}$ state, which is observed in human somatic tissues, triggering a choice between two equal $\mathrm{Xd}$ chromosomes for one of them to become the $\mathrm{Xi}$, unknown. $\mathrm{X}$ chromosome dampening has also been described in XX human pluripotent stem cells (hPSCs, the ex-vivo model of choice to investigate human XCI dynamics) during the conversion from primed to naïve pluripotency state: using bulk RNA-seq datasets, the authors have shown that initial reactivation of the inactive $X$ chromosome from primed to early naïve state was subsequently followed by X-dampening in late naïve cells [121,122].

The dampening model remains controversial and has been contested both in preimplantation embryos and hPSCs-see [123-125] for reviews. While reanalyzing the same transcriptome dataset published in Petropoulos et al. (2016) with more stringent conditions, De Mello et al. observed a decrease in the proportion of biallelically expressed X-linked genes, which is consistent with $\mathrm{XCI}$, and a constant level of their median expression hence refuting the hypothesis of $\mathrm{X}$-dampening and suggesting that human initiation of dosage compensation rather occurs through direct $X$-inactivation [18]. In agreement with the direct X-inactivation model, Mandal et al. observed partial X-reactivation of the inactive $\mathrm{X}$-chromosome rather than $\mathrm{Xd} / \mathrm{Xd}$ dampening in hPSCs reverting from primed to naïve state [126], when re-analyzing published single-cell RNA-seq datasets [122]. Although the dynamics of human dosage compensation initiation are debated, an additional lncRNA, $X A C T$, has been proposed to underlie choice [79]; interestingly, XACT accumulates in cis on both (active) $\mathrm{X}$ chromosomes in an "antagonistic" manner to XIST, i.e., regions of the $\mathrm{X}$ not covered by XIST are covered by XACT, as if they repel each other $[79,127]$.

\section{Preferences in Choice: Random XCI Patterns Are Often Skewed}

In theory, both $\mathrm{X}$ chromosomes during random XCI have the same probability of being inactivated-this would of course be the case if both chromosomes were genetically identical (which does not occur in wild populations, including human ones, but happens in inbred strains in laboratories) or if, of their genetic differences, none would influence the mechanisms of choice. However, deviations from 50:50 in patterns of inactivation are often observed. This skewing can occur as (i) a result of stochasticity, (ii) due to non-random choice at the onset of XCI, known as 'primary' choice, or (iii) as a result of selection for or against cells carrying one specific active or inactive $\mathrm{X}$ chromosome, known as 'secondary' choice [128-131]. Random XCI skewing due to stochastic events implies that, in the absence of genetic differences at the Xic or mutations in any other part of the $\mathrm{X}$ chromosomes that 
significantly affect the mechanisms of choice, more than half of the cells in an embryo (or adult) end up with the same inactive $X$. This phenomenon has been observed in inbred mice that carry different parent-of-origin fluorescent tags on either of their chromosomes but are otherwise genetically identical [132]. These mice show a high degree of XCI mosaicism between littermate siblings and even across tissues in the same individual, with sometimes as much as $90 \%$ of the cells of a tissue carrying the same inactive $X$, based only (presumably) on "stochastic choice" [132].

In humans, several studies have investigated the prevalence of skewed XCI in "phenotypically unaffected" XX individuals and reported widely different results, with the percentages of individuals showing skewed XCI ranging from less than $10 \%$ to over $50 \%$ [133-138]; these variations could depend on the degree of skewing considered, the analysis method, the type of tissue analyzed, and/or the age of the persons. For instance, a study among one thousand XX human individuals found skewed XCI in a large proportion of phenotypically healthy individuals, with $\sim 15 \%$ of adults exhibiting skewing greater than $80: 20$ in peripheral blood lymphocytes [135]. Whichever the degree of skewing, such stochastic-related imbalances reflect the ratio of "founder" cells to adult cells in specific tissues and organs, as well as the timing and extent of cell migration during development [132]; importantly, XCI is initiated at a time when the number of cells in the embryo is limited, hence achieving a perfect $50-50 \%$ inactivation ratio is not the most statistically likely event, already at the moment of XCI initiation [138]. Yet, given the high heterozygosity in the human population, another possibility is that the observed random skewing is in fact primary skewing, with individual variations (e.g., SNPs) at X-linked loci potentially leading to skewed XCI due to a preferential choice of one $X$ chromosome over the other at the time of XCI initiation (analogous to Xce alleles in mice, discussed below).

In primary skewing, potentially any variant in genes involved in the XCI process itself (usually genes within the Xic) could influence choice by having an impact on the upregulation of Xist and/or on the feedback loop that keeps one X from expressing Xist when the other started inactivating; the result would be that one $X$ chromosome is preferentially selected for inactivation as XCI starts in early development. An example of primary skewing is the modulation of XCI initiation by different X controlling element (Xce) alleles in mice: mouse strains from different genetic backgrounds carry unique Xce alleles that result in skewing phenotypes in the progeny of hybrid crosses [139]. The Xce segment has not been clearly defined and, so far, the different attempts to map it have located it close or overlapping with the Xic [139-143]; reviewed in [144]. One study even suggests that it is not just one locus but that the Xce may include different X-linked regions [143]. Importantly, not all those studies use the same approach to measure the "Xce effect" and therefore they might be effectively mapping regions that contribute to skewing in XCI patterns for hybrid crosses but not necessarily the Xce locus as originally defined [139]. Overall, six competing Xce alleles have been proposed, with the order of strength being $a<f<e<b<c<d$, where $X c e^{a}$ is the most likely to be inactivated and Xce $e^{d}$ the least likely. A new study has identified an additional allele, reportedly the weakest in the Xce allelic series [145]. In Xce heterozygotes, the X chromosome carrying the weaker of the two alleles is more likely to be inactivated. The degree of skewing can vary a lot, with cases of mean $X$ inactivation patterns as profound as $\sim 25: 75$ in $X c e^{c} / X c e^{a}$ hybrids [140]. Conversely, primary choice is presumably unbiased in Xce homozygotes. In humans, a locus homologous to the murine Xce has not yet been found, perhaps owing to the unique challenges faced when studying our species [146].

The so-called secondary skewing takes place post-XCI, when cells are selected either for or against depending on which $X$ chromosome they inactivated-reviewed in [147]. This mechanism occurs for instance in individuals that carry $X$-chromosome-linked variants associated with lethality or restricted survival and is often a hallmark of situations such as being a carrier for X-linked diseases [128,148]. In XX individuals with a structurally abnormal X chromosome (with deletions or duplications) or carrying unbalanced X:autosome translocations, cells that have inactivated the affected chromosome, in such a way that the 
normal X-chromosome and autosomal dosages are preserved, are positively selected for survival [149]. Another example of this mechanism can be found in XX individuals with Rett syndrome, a neurodevelopmental disorder caused by a mutation in the X-linked gene MECP2: unlike $\mathrm{XY}$ individuals, who often die of the condition, $\mathrm{XX}$ people can survive due to counter-selection of cells carrying the mutated $X$ chromosome $[70,150,151]$. On the other hand, females with balanced $X$ :autosome rearrangements usually inactivate the normal $\mathrm{X}$ chromosome in order to preserve functional expression of autosomal genes on the translocated segment [152]. An example of this situation is the manifestation of clinical symptoms in women heterozygous for mutations in the X-linked DMD gene, which, when not functional, results in Duchenne muscular dystrophy, a recessive disease. Several studies have reported cases of women with Xp21; A translocation and preferential inactivation (due to secondary skewing) of the wild-type $X$ chromosome-reviewed in [153]. While inactivation of the wild-type fully-functional copy of the DMD gene in these individuals may seem counterintuitive, this mechanism likely prevents monosomy of autosomal genes [154,155], a potentially lethal condition that could occur if the translocated X-chromosome segment (carrying the mutated DMD gene) were to be inactivated.

\section{XCI Choice: The Second Most Important Moment in the Lives of XX Mammals?}

Gastrulation has been considered the most important time in our lives, as famously noted by the pioneering developmental biologist Lewis Wolpert, who sadly left us earlier this year [156]. For placental mammals with two X chromosomes, another critical moment in their lives is when, in each of their cells, one of their X chromosomes becomes inactivated. This choice, and the patterns of gene expression that derive from it, can have significant implications. XCI is a major source of diversity within and between XX individuals; it generates stochastic, spatial mosaicism in gene expression across tissues and organs, which can affect their function. While in organs in which many cells perform the same function this might be of little phenotypic consequence, such region-to-region or sometimes left-toright diversity can lead to uncompensated phenotypes in organs with spatially segregated functions, such as sensory tissues and those part of the central nervous system [132].

In some cases, the choice of which $X$ chromosome to inactivate can make the difference between being healthy and unhealthy, as observed for genetically identical (monozygotic) twins who are phenotypically discordant for genetic diseases carried on the $X$ chromosome. Given that an X chromosome contains 1/20 of the genome's genes, identical XX twins can potentially differ by up to $5 \%$ in the genes they use [157]. For instance, casestudies in $X X$ twins carrying a mutation for Duchenne muscular dystrophy have reported that a skewed XCI pattern renders one twin ill with the disease while the other remains unaffected [158-160].

The relationship between XCI choice and the phenotypical manifestation of X-linked mutations could perhaps inform the long-standing question of why (or rather how) rXCI evolved. The process that leads to the choice of which $X$ to inactivate is especially puzzling in mice: why does the system selectively inactivate the $\mathrm{Xp}$ in the preimplantation embryo, only to reactivate it and randomly re-inactivate it again upon implantation? An attractive hypothesis is that $\mathrm{rXCI}$ could have been selected to limit the consequences of detrimental $X$-linked mutations in XX individuals; but then why did the same mechanism not evolve in marsupials? Could it be that differences in gene content between the placental and marsupial $X$ are such that marsupial $X$ chromosomes are globally "less affected" by mutations? The answer is probably connected to the different constraints and pressures to which the $X$ chromosome is subject to in these lineages. It will be fascinating to explore these questions in the future.

Finally, is choice reversible? Once established, XCI is mitotically heritable, i.e., daughter cells have the same inactive $X$ as their mother cell, so choice is propagated and skewed spatial patterns maintained. The reactivation of the inactive $X$ chromosome can happen spontaneously (though very rarely), in pathological contexts or in specific developmental 
moments, such as in the cells that will produce the embryo proper in mice or during oogenesis-reviewed in [125,161-163].

Clinically, efforts are ongoing to develop strategies for inducing reactivation of the inactive $X$ in patients-for instance, targeted $X$-reactivation methods are underway to help young $X X$ individuals affected by Rett syndrome, who carry an active $X$ chromosome harbouring a mutated allele of the $M E C P 2$ gene and an inactive $\mathrm{X}$ chromosome harbouring a wildtype allele [151,164-166]. "Awakening" their Xi could restore MECP2 function and cure Rett syndrome. Understanding how choice is established-and how it could be reversed-will therefore remain an important subject of investigation in the X-inactivation field, with wider implications for how we think about epigenetic mechanisms, networks of gene regulation and developmental decisions.

Funding: G.F. has been supported by an EMBO Long-Term fellowship (EMBO ALTF 1132-2018). R.G. has been supported by a fellowship from the European Molecular Biology Laboratory Interdisciplinary Postdoc Programme (EIPOD) under Marie Skłodowska-Curie Actions COFUND (664726).

Acknowledgments: We thank our mentors Claire Rougeulle and Edith Heard for having "initiated" us into X-inactivation and for giving us the "choice" to explore the topic in our own ways during our PhDs. We apologise to authors whose valuable work we overlooked and/or did not cite here due to space constraints.

Conflicts of Interest: The authors declare no conflict of interest.

\section{References}

1. Disteche, C.M. Dosage Compensation of the Sex Chromosomes. Annu. Rev. Genet. 2012, 46, 537-560. [CrossRef] [PubMed]

2. Lyon, M.F. Gene Action in the X-chromosome of the Mouse (Mus musculus L.). Nature 1961, 190, 372-373. [CrossRef] [PubMed]

3. Whitworth, D.J.; Pask, A.J. The $X$ factor: $X$ chromosome dosage compensation in the evolutionarily divergent monotremes and marsupials. Semin. Cell Dev. Biol. 2016, 56, 117-121. [CrossRef]

4. Sharman, G.B. Late DNA Replication in the Paternally Derived X Chromosome of Female Kangaroos. Nature 1971, $230,231-232$. [CrossRef] [PubMed]

5. $\quad$ Evans, H.J.; Ford, C.E.; Lyon, M.F.; Gray, J.; Evans, C.E.F.H.J. DNA Replication and Genetic Expression in Female Mice with Morphologically Distinguishable X Chromosomes. Nature 1965, 206, 900-903. [CrossRef] [PubMed]

6. Okamoto, I.; Otte, A.P.; Allis, C.D.; Reinberg, D.; Heard, E. Epigenetic Dynamics of Imprinted X Inactivation During Early Mouse Development. Science 2004, 303, 644-649. [CrossRef] [PubMed]

7. Takagi, N.; Sasaki, M. Preferential inactivation of the paternally derived X chromosome in the extraembryonic membranes of the mouse. Nature 1975, 256, 640-642. [CrossRef] [PubMed]

8. Harper, M.I.; Fosten, M.; Monk, M. Preferential paternal X inactivation in extraembryonic tissues of early mouse embryos. Development 1982, 67, 127-135. [CrossRef]

9. Huynh, K.D.; Lee, J.T. Inheritance of a pre-inactivated paternal X chromosome in early mouse embryos. Nature 2003, 426, 857-862. [CrossRef]

10. Latham, K.E. X chromosome imprinting and inactivation in the early mammalian embryo. Trends Genet. 1996, 12, 134-138. [CrossRef]

11. Mak, W.; Nesterova, T.B.; de Napoles, M.; Appanah, R.; Yamanaka, S.; Otte, A.P.; Brockdorff, N. Reactivation of the Paternal X Chromosome in Early Mouse Embryos. Science 2004, 303, 666-669. [CrossRef]

12. West, J.D.; Frels, W.I.; Chapman, V.M.; Papaioannou, V. Preferential expression of the maternally derived X chromosome in the mouse yolk sac. Cell 1977, 12, 873-882. [CrossRef]

13. Wake, N.; Takagi, N.; Sasaki, M. Non-random inactivation of X chromosome in the rat yolk sac. Nature 1976, $262,580-581$. [CrossRef]

14. Dindot, S.V.; Kent, K.C.; Evers, B.; Loskutoff, N.; Womack, J.; Piedrahita, J.A. Conservation of genomic imprinting at the XIST, IGF2, and GTL2 loci in the bovine. Mamm. Genome 2004, 15, 966-974. [CrossRef]

15. Xue, F.; Tian, X.C.; Du, F.; Kubota, C.; Taneja, M.; Dinnyes, A.; Dai, Y.; Levine, H.; Pereira, L.V.; Yang, X. Aberrant patterns of X chromosome inactivation in bovine clones. Nat. Genet. 2002, 31, 216-220. [CrossRef]

16. Goto, T.; Wright, E.; Monk, M. Paternal X-chromosome inactivation in human trophoblastic cells. Mol. Hum. Reprod. 1997, 3, 77-80. [CrossRef]

17. Harrison, K. X-chromosome inactivation in the human cytotrophoblast. Cytogenet. Genome Res. 1989, 52, 37-41. [CrossRef]

18. De Mello, J.C.M.; De Araújo, É.S.S.; Stabellini, R.; Fraga, A.M.; De Souza, J.E.S.; Sumita, D.R.; Camargo, A.A.; Pereira, L.V. Random X Inactivation and Extensive Mosaicism in Human Placenta Revealed by Analysis of Allele-Specific Gene Expression along the X Chromosome. PLoS ONE 2010, 5, e10947. [CrossRef] 
19. Hamada, H.; Okae, H.; Toh, H.; Chiba, H.; Hiura, H.; Shirane, K.; Sato, T.; Suyama, M.; Yaegashi, N.; Sasaki, H.; et al. AlleleSpecific Methylome and Transcriptome Analysis Reveals Widespread Imprinting in the Human Placenta. Am. J. Hum. Genet. 2016, 99, 1045-1058. [CrossRef]

20. Okamoto, I.; Patrat, C.; Thépot, D.; Peynot, N.; Fauque, P.; Daniel, N.; Diabangouaya, P.; Wolf, J.-P.; Renard, J.-P.; Duranthon, V.; et al. Eutherian mammals use diverse strategies to initiate X-chromosome inactivation during development. Nature 2011, 472, 370-374. [CrossRef]

21. Zou, H.; Yu, D.; Du, X.; Wang, J.; Chen, L.; Wang, Y.; Xu, H.; Zhao, Y.; Zhao, S.; Pang, Y.; et al. No imprinted XIST expression in pigs: Biallelic XIST expression in early embryos and random X inactivation in placentas. Cell. Mol. Life. Sci. 2019, 76, 4525-4538. [CrossRef]

22. Ramos-Ibeas, P.; Sang, F.; Zhu, Q.; Tang, W.W.C.; Withey, S.; Klisch, D.; Wood, L.; Loose, M.; Surani, M.A.; Alberio, R. Pluripotency and $X$ chromosome dynamics revealed in pig pre-gastrulating embryos by single cell analysis. Nat. Commun. 2019, 10, 1-17. [CrossRef]

23. Okamoto, I.; Nakamura, T.; Sasaki, K.; Yabuta, Y.; Iwatani, C.; Tsuchiya, H.; Nakamura, S.-I.; Ema, M.; Yamamoto, T.; Saitou, M. The $\mathrm{X}$ chromosome dosage compensation program during the development of cynomolgus monkeys. Science 2021, 374 , eabd8887. [CrossRef]

24. Dossin, F.; Heard, E. The Molecular and Nuclear Dynamics of X-Chromosome Inactivation. Cold Spring Harb. Perspect. Biol. 2021, 22, a040196. [CrossRef]

25. Penny, G.D.; Kay, G.F.; Sheardown, S.A.; Rastan, S.; Brockdorff, N. Requirement for Xist in X chromosome inactivation. Nature 1996, 379, 131-137. [CrossRef]

26. Borensztein, M.; Syx, L.; Ancelin, K.; Diabangouaya, P.; Picard, C.; Liu, T.; Liang, J.-B.; Vassilev, I.; Galupa, R.; Servant, N.; et al. Xist-dependent imprinted X inactivation and the early developmental consequences of its failure. Nat. Struct. Mol. Biol. 2017, 24, 226-233. [CrossRef]

27. Namekawa, S.H.; Payer, B.; Huynh, K.D.; Jaenisch, R.; Lee, J.T. Two-Step Imprinted X Inactivation: Repeat versus Genic Silencing in the Mouse. Mol. Cell. Biol. 2010, 30, 3187-3205. [CrossRef]

28. Grant, J.; Mahadevaiah, S.K.; Khil, P.; Sangrithi, M.; Royo, H.; Duckworth, J.; McCarrey, J.R.; VandeBerg, J.L.; Renfree, M.; Taylor, W.; et al. Rsx is a metatherian RNA with Xist-like properties in X-chromosome inactivation. Nature 2012, 487, 254-258. [CrossRef]

29. Singh, D.; Sun, D.; King, A.G.; Alquezar-Planas, D.E.; Johnson, R.N.; Alvarez-Ponce, D.; Yi, S.V. Koala methylomes reveal divergent and conserved DNA methylation signatures of X chromosome regulation. Proc. R. Soc. B Boil. Sci. 2021, $288,20202244$. [CrossRef]

30. Wang, X.; Douglas, K.C.; VandeBerg, J.L.; Clark, A.G.; Samollow, P.B. Chromosome-wide profiling of X-chromosome inactivation and epigenetic states in fetal brain and placenta of the opossum, Monodelphis domestica. Genome Res. 2013, 24, 70-83. [CrossRef]

31. Kay, G.F.; Barton, S.C.; Surani, A.; Rastan, S. Imprinting and X chromosome counting mechanisms determine Xist expression in early mouse development. Cell 1994, 77, 639-650. [CrossRef]

32. Mullins, L.J.; Veres, G.; Caskey, C.T.; Chapman, V. Differential methylation of the ornithine carbamoyl transferase gene on active and inactive mouse X chromosomes. Mol. Cell. Biol. 1987, 7, 3916-3922. [CrossRef] [PubMed]

33. Sanford, J.P.; Clark, H.J.; Chapman, V.M.; Rossant, J. Differences in DNA methylation during oogenesis and spermatogenesis and their persistence during early embryogenesis in the mouse. Genes Dev. 1987, 1, 1039-1046. [CrossRef] [PubMed]

34. Monk, M.; Boubelik, M.; Lehnert, S. Temporal and regional changes in DNA methylation in the embryonic, extraembryonic and germ cell lineages during mouse embryo development. Development 1987, 99, 371-382. [CrossRef]

35. Krumlauf, R.; Chapman, V.M.; Hammer, R.E.; Brinster, R.; Tilghman, S.M. Differential expression of $\alpha$-fetoprotein genes on the inactive $X$ chromosome in extraembryonic and somatic tissues of a transgenic mouse line. Nature 1986, 319, 224-226. [CrossRef]

36. Grant, S.G.; Chapman, V.M. Mechanisms of X-chromosome Regulation. Annu. Rev. Genet. 1988, 22, 199-233. [CrossRef]

37. Lifschytz, E.; Lindsley, D.L. The Role of X-Chromosome Inactivation during Spermatogenesis. Proc. Natl. Acad. Sci. USA 1972, 69, 182-186. [CrossRef]

38. Cloutier, J.M.; Turner, J.M. Meiotic sex chromosome inactivation. Curr. Biol. 2010, 20, R962-R963. [CrossRef]

39. Cooper, D.W. Directed Genetic Change Model for X Chromosome Inactivation in Eutherian Mammals. Nature 1971, $230,292-294$. [CrossRef]

40. Kalantry, S.; Purushothaman, S.; Bowen, R.B.; Starmer, J.; Magnuson, T. Evidence of Xist RNA-independent initiation of mouse imprinted X-chromosome inactivation. Nature 2009, 460, 647-651. [CrossRef]

41. Okamoto, I.; Arnaud, D.; Le Baccon, P.; Otte, A.P.; Disteche, C.M.; Avner, P.; Heard, E. Evidence for de novo imprinted X-chromosome inactivation independent of meiotic inactivation in mice. Nature 2005, 438, 369-373. [CrossRef]

42. Patrat, C.; Okamoto, I.; Diabangouaya, P.; Vialon, V.; Le Baccon, P.; Chow, J.; Heard, E. Dynamic changes in paternal X-chromosome activity during imprinted X-chromosome inactivation in mice. Proc. Natl. Acad. Sci. USA 2009, 106, 5198-5203. [CrossRef]

43. Duret, L.; Chureau, C.; Samain, S.; Weissenbach, J.; Avner, P. The Xist RNA Gene Evolved in Eutherians by Pseudogenization of a Protein-Coding Gene. Science 2006, 312, 1653-1655. [CrossRef]

44. Hore, T.A.; Koina, A.; Wakefield, M.J.; Graves, J.A.M. The region homologous to the X-chromosome inactivation centre has been disrupted in marsupial and monotreme mammals. Chromosom. Res. 2007, 15, 147-161. [CrossRef]

45. Davidow, L.S.; Breen, M.; Duke, S.E.; Samollow, P.B.; McCarrey, J.R.; Lee, J.T. The search for a marsupial XIC reveals a break with vertebrate synteny. Chromosom. Res. 2007, 15, 137-146. [CrossRef] 
46. Shevchenko, A.I.; Zakharova, I.S.; Elisaphenko, E.A.; Kolesnikov, N.N.; Whitehead, S.; Bird, C.; Ross, M.; Weidman, J.R.; Jirtle, R.L.; Karamysheva, T.V.; et al. Genes flanking Xist in mouse and human are separated on the X chromosome in American marsupials. Chromosom. Res. 2007, 15, 127-136. [CrossRef]

47. Mahadevaiah, S.K.; Royo, H.; VandeBerg, J.L.; McCarrey, J.R.; Mackay, S.; Turner, J.M. Key Features of the X Inactivation Process Are Conserved between Marsupials and Eutherians. Curr. Biol. 2009, 19, 1478-1484. [CrossRef]

48. Lyon, M.F.; Rastan, S. Parental source of chromosome imprinting and its relevance for X chromosome inactivation. Differentiation 1984, 26, 63-67. [CrossRef]

49. Tada, T.; Obata, Y.; Tada, M.; Goto, Y.; Nakatsuji, N.; Tan, S.; Kono, T.; Takagi, N. Imprint switching for non-random X-chromosome inactivation during mouse oocyte growth. Development 2000, 127, 3101-3105. [CrossRef]

50. Goto, Y.; Takagi, N. Tetraploid embryos rescue embryonic lethality caused by an additional maternally inherited X chromosome in the mouse. Development 1998, 125, 3353-3363. [CrossRef]

51. Tada, T.; Takagi, N.; Adler, I.-D. Parental imprinting on the mouse X chromosome: Effects on the early development of X0, XXY and XXX embryos. Genet. Res. 1993, 62, 139-148. [CrossRef]

52. Shao, C.; Takagi, N. An extra maternally derived X chromosome is deleterious to early mouse development. Development 1990, 110, 969-975. [CrossRef]

53. Kaufman, M.H.; Guc-Cubrilo, M.; Lyon, M.F.; Kaufman, M.G.-C.M.H. X chromosome inactivation in diploid parthenogenetic mouse embryos. Nature 1978, 271, 547-549. [CrossRef] [PubMed]

54. Rastan, S.; Kaufman, M.H.; Handyside, A.H.; Lyon, M.F. X-chromosome inactivation in extra-embryonic membranes of diploid parthenogenetic mouse embryos demonstrated by differential staining. Nature 1980, 288, 172-173. [CrossRef]

55. Oikawa, M.; Inoue, K.; Shiura, H.; Matoba, S.; Kamimura, S.; Hirose, M.; Mekada, K.; Yoshiki, A.; Tanaka, S.; Abe, K.; et al Understanding the $X$ chromosome inactivation cycle in mice. Epigenetics 2014, 9, 204-211. [CrossRef]

56. Hanna, C.W.; Kelsey, G. Features and mechanisms of canonical and noncanonical genomic imprinting. Genes Dev. 2021, 35, 821-834. [CrossRef]

57. Chiba, H.; Hirasawa, R.; Kaneda, M.; Amakawa, Y.; Li, E.; Sado, T.; Sasaki, H. De novoDNA methylation independent establishment of maternal imprint on X chromosome in mouse oocytes. Genes 2008, 46, 768-774. [CrossRef] [PubMed]

58. Inoue, A.; Jiang, L.; Lu, F.; Suzuki, T.; Zhang, Y. Maternal H3K27me3 controls DNA methylation-independent imprinting. Nature 2017, 547, 419-424. [CrossRef]

59. Inoue, A.; Jiang, L.; Lu, F.; Zhang, Y. Genomic imprinting of Xist by maternal H3K27me3. Genes Dev. 2017, 31, 1927-1932. [CrossRef]

60. Collombet, S.; Ranisavljevic, N.; Nagano, T.; Varnai, C.; Shisode, T.; Leung, W.; Piolot, T.; Galupa, R.; Borensztein, M.; Servant, N.; et al. Parental-to-Embryo Switch of Chromosome Organization in Early Embryogenesis. Obstet. Gynecol. Surv. 2020, 75, 414-415. [CrossRef]

61. Fukuda, A.; Tomikawa, J.; Miura, T.; Hata, K.; Nakabayashi, K.; Eggan, K.; Akutsu, H.; Umezawa, A. The role of maternal-specific H3K9me3 modification in establishing imprinted X-chromosome inactivation and embryogenesis in mice. Nat. Commun. 2014, 5, 5464. [CrossRef]

62. Furlan, G.; Hernandez, N.G.; Huret, C.; Galupa, R.; van Bemmel, J.G.; Romito, A.; Heard, E.; Morey, C.; Rougeulle, C. The Ftx Noncoding Locus Controls X Chromosome Inactivation Independently of Its RNA Products. Mol. Cell 2018, 70, 462-472.e8. [CrossRef]

63. Tian, D.; Sun, S.; Lee, J.T. The Long Noncoding RNA, Jpx, Is a Molecular Switch for X Chromosome Inactivation. Cell 2010, 143, 390-403. [CrossRef]

64. Lee, J.T.; Lu, N. Targeted Mutagenesis of Tsix Leads to Nonrandom X Inactivation. Cell 1999, 99, 47-57. [CrossRef]

65. Lee, J.T. Disruption of Imprinted X Inactivation by Parent-of-Origin Effects at Tsix. Cell 2000, 103, 17-27. [CrossRef]

66. Sado, T.; Wang, Z.; Sasaki, H.; Li, E. Regulation of imprinted X-chromosome inactivation in mice by Tsix. Development 2001, 128, 1275-1286. [CrossRef]

67. Soma, M.; Fujihara, Y.; Okabe, M.; Ishino, F.; Kobayashi, S. Ftx is dispensable for imprinted X-chromosome inactivation in preimplantation mouse embryos. Sci. Rep. 2014, 4, 5181. [CrossRef] [PubMed]

68. Mahadevaiah, S.K.; Sangrithi, M.N.; Hirota, T.; Turner, J.M.A. A single-cell transcriptome atlas of marsupial embryogenesis and X inactivation. Nature 2020, 586, 612-617. [CrossRef]

69. McLay, D.W.; Clarke, H.J. Remodelling the paternal chromatin at fertilization in mammals. Reproduction 2003, 125, 625. [CrossRef]

70. Lee, J.T.; Bartolomei, M.S. X-Inactivation, Imprinting, and Long Noncoding RNAs in Health and Disease. Cell 2013, 152, 1308-1323. [CrossRef] [PubMed]

71. Namekawa, S.H.; VandeBerg, J.L.; McCarrey, J.R.; Lee, J.T. Sex chromosome silencing in the marsupial male germ line. Proc. Natl. Acad. Sci. USA 2007, 104, 9730-9735. [CrossRef] [PubMed]

72. Brown, S.W.; Chandra, H.S. Inactivation System of the Mammalian X Chromosome. Proc. Natl. Acad. Sci. USA 1973, 70, 195-199. [CrossRef]

73. Berg, I.M.V.D.; Galjaard, R.J.; Laven, J.S.E.; van Doorninck, J.H. XCI in preimplantation mouse and human embryos: First there is remodelling .... Qual. Life Res. 2011, 130, 203-215. [CrossRef]

74. Sado, T. What makes the maternal X chromosome resistant to undergoing imprinted X inactivation? Philos. Trans. R. Soc. B Biol. Sci. 2017, 372, 20160365. [CrossRef] 
75. Sado, T.; Sakaguchi, T. Species-specific differences in X chromosome inactivation in mammals. Reproduction 2013, 146, R131-R139. [CrossRef]

76. Mutzel, V.; Okamoto, I.; Dunkel, I.; Saitou, M.; Giorgetti, L.; Heard, E.; Schulz, E.G. A symmetric toggle switch explains the onset of random X inactivation in different mammals. Nat. Struct. Mol. Biol. 2019, 26, 350-360. [CrossRef]

77. Marahrens, Y.; Panning, B.; Dausman, J.; Strauss, W.; Jaenisch, R. Xist-deficient mice are defective in dosage compensation but not spermatogenesis. Genes Dev. 1997, 11, 156-166. [CrossRef]

78. Petropoulos, S.; Edsgärd, D.; Reinius, B.; Deng, Q.; Panula, S.P.; Codeluppi, S.; Reyes, A.P.; Linnarsson, S.; Sandberg, R.; Lanner F. Single-Cell RNA-Seq Reveals Lineage and X Chromosome Dynamics in Human Preimplantation Embryos. Cell 2016, 165, 1012-1026. [CrossRef]

79. Vallot, C.; Patrat, C.; Collier, A.; Huret, C.; Casanova, M.; Ali, T.M.L.; Tosolini, M.; Frydman, N.A.; Heard, E.; Rugg-Gunn, P.; et al. XACT Noncoding RNA Competes with XIST in the Control of X Chromosome Activity during Human Early Development. Cell Stem Cell 2017, 20, 102-111. [CrossRef]

80. Mutzel, V.; Schulz, E.G. Dosage Sensing, Threshold Responses, and Epigenetic Memory: A Systems Biology Perspective on Random X-Chromosome Inactivation. BioEssays 2020, 42, e1900163. [CrossRef]

81. Enervald, E.; Powell, L.M.; Boteva, L.; Foti, R.; Ruiz, N.B.; Kibar, G.; Piszczek, A.; Cavaleri, F.; Vingron, M.; Cerase, A.; et al. RIF1 and KAP1 differentially regulate the choice of inactive versus active $\mathrm{X}$ chromosomes. EMBO J. 2021, 40, e105862. [CrossRef] [PubMed]

82. Makhlouf, M.; Ouimette, J.-F.; Oldfield, A.; Navarro, P.; Neuillet, D.; Rougeulle, C. A prominent and conserved role for YY1 in Xist transcriptional activation. Nat. Commun. 2014, 5, 4878. [CrossRef]

83. Sun, B.; Deaton, A.; Lee, J.T. A Transient Heterochromatic State in Xist Preempts X Inactivation Choice without RNA Stabilization Mol. Cell 2006, 21, 617-628. [CrossRef] [PubMed]

84. Sado, T.; Hoki, Y.; Sasaki, H. Tsix Silences Xist through Modification of Chromatin Structure. Dev. Cell 2005, 9, 159-165. [CrossRef]

85. Navarro, P.; Page, D.R.; Avner, P.; Rougeulle, C. Tsix-mediated epigenetic switch of a CTCF-flanked region of the Xist promoter determines the Xist transcription program. Genes Dev. 2006, 20, 2787-2792. [CrossRef]

86. Debrand, E.; Chureau, C.; Arnaud, D.; Avner, P.; Heard, E. Functional Analysis of the DXPas34 Locus, a 3' Regulator of Xist Expression. Mol. Cell. Biol. 1999, 19, 8513-8525. [CrossRef]

87. Yin, H.; Wei, C.; Lee, J.T. Revisiting the consequences of deleting the X inactivation center. Proc. Natl. Acad. Sci. USA 2021, 118 [CrossRef]

88. Loda, A.; Brandsma, J.H.; Vassilev, I.; Servant, N.; Loos, F.; Amirnasr, A.; Splinter, E.; Barillot, E.; Poot, R.A.; Heard, E.; et al. Genetic and epigenetic features direct differential efficiency of Xist-mediated silencing at X-chromosomal and autosomal locations. Nat. Commun. 2017, 8, 690. [CrossRef]

89. Sado, T.; Hoki, Y.; Sasaki, H. Tsix defective in splicing is competent to establish Xist silencing. Development 2006, 133, 4925-4931. [CrossRef]

90. Shibata, S.; Lee, J.T. Tsix Transcription- versus RNA-Based Mechanisms in Xist Repression and Epigenetic Choice. Curr. Biol. 2004, 14, 1747-1754. [CrossRef]

91. Luikenhuis, S.; Wutz, A.; Jaenisch, R. Antisense Transcription through the Xist Locus Mediates Tsix Function in Embryonic Stem Cells. Mol. Cell. Biol. 2001, 21, 8512-8520. [CrossRef] [PubMed]

92. Navarro, P.; Pichard, S.; Ciaudo, C.; Avner, P.; Rougeulle, C. Tsix transcription across the Xist gene alters chromatin conformation without affecting Xist transcription: Implications for X-chromosome inactivation. Genes Dev. 2005, 19, 1474-1484. [CrossRef] [PubMed]

93. Ohhata, T.; Hoki, Y.; Sasaki, H.; Sado, T. Crucial role of antisense transcription across the Xist promoter in Tsix-mediated Xist chromatin modification. Development 2008, 135, 227-235. [CrossRef] [PubMed]

94. Stavropoulos, N.; Lu, N.; Lee, J.T. A functional role for Tsix transcription in blocking Xist RNA accumulation but not in X-chromosome choice. Proc. Natl. Acad. Sci. USA 2001, 98, 10232-10237. [CrossRef]

95. Migeon, B.R.; Lee, C.H.; Chowdhury, A.K.; Carpenter, H. Species Differences in TSIX/Tsix Reveal the Roles of These Genes in X-Chromosome Inactivation. Am. J. Hum. Genet. 2002, 71, 286-293. [CrossRef]

96. Migeon, B.R.; Chowdhury, A.K.; Dunston, J.A.; McIntosh, I. Identification of TSIX, Encoding an RNA Antisense to Human XIST, Reveals Differences from its Murine Counterpart: Implications for X Inactivation. Am. J. Hum. Genet. 2001, 69, 951-960. [CrossRef]

97. Galupa, R.; Heard, E. X-Chromosome Inactivation: A Crossroads Between Chromosome Architecture and Gene Regulation. Annu. Rev. Genet. 2018, 52, 535-566. [CrossRef]

98. Ogawa, Y.; Lee, J.T. Xite, X-Inactivation Intergenic Transcription Elements that Regulate the Probability of Choice. Mol. Cell 2003, 11, 731-743. [CrossRef]

99. Galupa, R.; Nora, E.P.; Worsley-Hunt, R.; Picard, C.; Gard, C.; van Bemmel, J.G.; Servant, N.; Zhan, Y.; El Marjou, F.; Johanneau, C.; et al. A Conserved Noncoding Locus Regulates Random Monoallelic Xist Expression across a Topological Boundary. Mol. Cell 2020, 77, 352-367.e8. [CrossRef]

100. Tena, J.J.; Santos-Pereira, J.M. Topologically Associating Domains and Regulatory Landscapes in Development, Evolution and Disease. Front. Cell Dev. Biol. 2021, 9, 1817. [CrossRef] 
101. Nora, E.; Lajoie, B.R.; Schulz, E.G.; Giorgetti, L.; Okamoto, I.; Servant, N.; Piolot, T.; Van Berkum, N.L.; Meisig, J.; Sedat, J.; et al. Spatial partitioning of the regulatory landscape of the X-inactivation centre. Nature 2012, 485, 381-385. [CrossRef]

102. Dixon, J.R.; Selvaraj, S.; Yue, F.; Kim, A.; Li, Y.; Shen, Y.; Hu, M.; Liu, J.S.; Ren, B. Topological domains in mammalian genomes identified by analysis of chromatin interactions. Nature 2012, 485, 376-380. [CrossRef]

103. Van Bemmel, J.G.; Galupa, R.; Gard, C.; Servant, N.; Picard, C.; Davies, J.; Szempruch, A.J.; Zhan, Y.; Żylicz, J.J.; Nora, E.P.; et al. The bipartite TAD organization of the $X$-inactivation center ensures opposing developmental regulation of Tsix and Xist. Nat. Genet. 2019, 51, 1024-1034. [CrossRef]

104. Gjaltema, R.A.; Schwämmle, T.; Kautz, P.; Robson, M.; Schöpflin, R.; Lustig, L.R.; Brandenburg, L.; Dunkel, I.; Vechiatto, C.; Ntini, E.; et al. Distal and proximal cis-regulatory elements sense $\mathrm{X}$ chromosome dosage and developmental state at the Xist locus. Mol. Cell 2021, 82, 190-208.e17. [CrossRef]

105. Rosspopoff, O.; Huret, C.; Collier, A.J.; Casanova, M.; Rugg-Gunn, P.J.; Ouimette, J.-F.; Rougeulle, C. Mechanistic diversifica-tion of XIST regulatory network in mammals. BioRxiv 2019, 689430.

106. Sun, S.; Del Rosario, B.C.; Szanto, A.; Ogawa, Y.; Jeon, Y.; Lee, J.T. Jpx RNA Activates Xist by Evicting CTCF. Cell 2013, 153, 1537-1551. [CrossRef]

107. Nesterova, T.B.; Johnston, C.M.; Appanah, R.; Newall, A.E.; Godwin, J.; Alexiou, M.; Brockdorff, N. Skewing X chromosome choice by modulating sense transcription across theXistlocus. Genes Dev. 2003, 17, 2177-2190. [CrossRef]

108. Sarkar, M.K.; Gayen, S.; Kumar, S.; Maclary, E.; Buttigieg, E.; Hinten, M.; Kumari, A.; Harris, C.; Sado, T.; Kalantry, S. An Xist-activating antisense RNA required for X-chromosome inactivation. Nat. Commun. 2015, 6, 8564. [CrossRef]

109. Dossin, F.; Pinheiro, I.; Zylicz, J.; Roensch, J.; Collombet, S.; Le Saux, A.; Chelmicki, T.; Attia, M.; Kapoor, V.; Zhan, Y.; et al. SPEN integrates transcriptional and epigenetic control of $X$-inactivation. Nature 2020, 578, 455-460. [CrossRef]

110. Robert-Finestra, T.; Tan, B.F.; Mira-Bontenbal, H.; Timmers, E.; Gontan, C.; Merzouk, S.; Giaimo, B.D.; Dossin, F.; van Ijcken, W.F.J.; Martens, J.W.M.; et al. SPEN is required for Xist upregulation during initiation of $\mathrm{X}$ chromosome inactivation. Nat. Commun. 2021, 12, 1-13. [CrossRef]

111. Schulz, E.G.; Nora, E.P.; Heard, E. Rnf12-A Jack of All Trades in X Inactivation? PLoS Genet. 2011, 7, e1002002. [CrossRef]

112. Monkhorst, K.; Jonkers, I.; Rentmeester, E.; Grosveld, F.; Gribnau, J. X Inactivation Counting and Choice Is a Stochastic Process: Evidence for Involvement of an X-Linked Activator. Cell 2008, 132, 410-421. [CrossRef]

113. Jonkers, I.; Barakat, T.S.; Achame, E.M.; Monkhorst, K.; Kenter, A.; Rentmeester, E.; Grosveld, F.; Grootegoed, J.A.; Gribnau, J. RNF12 Is an X-Encoded Dose-Dependent Activator of X Chromosome Inactivation. Cell 2009, 139, 999-1011. [CrossRef]

114. Gontan, C.; Achame, E.M.; Demmers, J.; Barakat, S.; Rentmeester, E.; van Ijcken, W.; Grootegoed, J.A.; Gribnau, J. RNF12 initiates X-chromosome inactivation by targeting REX1 for degradation. Nature 2012, 485, 386-390. [CrossRef]

115. Barakat, T.S.; Gunhanlar, N.; Pardo, C.G.; Achame, E.M.; Ghazvini, M.; Boers, R.; Kenter, A.; Rentmeester, E.; Grootegoed, J.A.; Gribnau, J. RNF12 Activates Xist and Is Essential for X Chromosome Inactivation. PLoS Genet. 2011, 7, e1002001. [CrossRef]

116. Shin, J.; Bossenz, M.; Chung, Y.; Ma, H.; Byron, M.; Taniguchi-Ishigaki, N.; Zhu, X.; Jiao, B.; Hall, L.L.; Green, M.R.; et al. Maternal Rnf12/RLIM is required for imprinted X-chromosome inactivation in mice. Nature 2010, 467, 977-981. [CrossRef]

117. Shin, J.; Wallingford, M.C.; Gallant, J.; Marcho, C.; Jiao, B.; Byron, M.; Bossenz, M.; Lawrence, J.B.; Jones, S.N.; Mager, J.; et al RLIM is dispensable for X-chromosome inactivation in the mouse embryonic epiblast. Nature 2014, 511, 86-89. [CrossRef]

118. Hayashi, S.; Lewis, P.; Pevny, L.; McMahon, A.P. Efficient gene modulation in mouse epiblast using a Sox2Cre transgenic mouse strain. Mech. Dev. 2002, 119, S97-S101. [CrossRef]

119. Zhou, Q.; Wang, T.; Leng, L.; Zheng, W.; Huang, J.; Fang, F.; Yang, L.; Chen, F.; Lin, G.; Wang, W.J.; et al. Single-cell RNA-seq reveals distinct dynamic behavior of sex chromosomes during early human embryogenesis. Mol. Reprod. Dev. 2019, 86, 871-882. [CrossRef]

120. Heard, E.; Rougeulle, C. Digging into X chromosome inactivation. Science 2021, 374, 942-943. [CrossRef]

121. Mekhoubad, S.; Bock, C.; de Boer, A.S.; Kiskinis, E.; Meissner, A.; Eggan, K. Erosion of Dosage Compensation Impacts Human iPSC Disease Modeling. Cell Stem Cell 2012, 10, 595-609. [CrossRef] [PubMed]

122. Sahakyan, A.; Kim, R.; Chronis, C.; Sabri, S.; Bonora, G.; Theunissen, T.; Kuoy, E.; Langerman, J.; Clark, A.T.; Jaenisch, R.; et al. Human Naive Pluripotent Stem Cells Model X Chromosome Dampening and X Inactivation. Cell Stem Cell 2017, $20,87-101$. [CrossRef] [PubMed]

123. Saiba, R.; Arava, M.; Gayen, S. Dosage compensation in human pre-implantation embryos: X-chromosome inactivation or dampening? EMBO Rep. 2018, 19, e46294. [CrossRef] [PubMed]

124. Kaur, H.; Rv, P.; Gayen, S. Dampened X-chromosomes in human pluripotent stem cells: Dampening or erasure of X-upregulation? Chromosoma 2019, 129, 111-113. [CrossRef] [PubMed]

125. Spaziano, A.; Cantone, I. X-chromosome reactivation: A concise review. Biochem. Soc. Trans. 2021, 49, 2797-2805. [CrossRef]

126. Mandal, S.; Chandel, D.; Kaur, H.; Majumdar, S.; Arava, M.; Gayen, S. Single-Cell Analysis Reveals Partial Reactivation of X Chromosome instead of Chromosome-wide Dampening in Naive Human Pluripotent Stem Cells. Stem Cell Rep. 2020, 14, 745-754. [CrossRef]

127. Casanova, M.; Moscatelli, M.; Chauvière, L.É.; Huret, C.; Samson, J.; Ali, T.M.L.; Rosspopoff, O.; Rougeulle, C. A primate-specific retroviral enhancer wires the XACT IncRNA into the core pluripotency network in humans. Nat. Commun. 2019, 10, 1-14. [CrossRef] 
128. Brown, C.; Robinson, W. The causes and consequences of random and non-random $\mathrm{X}$ chromosome inactivation in humans. Clin. Genet. 2000, 58, 353-363. [CrossRef]

129. Belmont, J.W. Genetic control of X inactivation and processes leading to X-inactivation skewing. Am. J. Hum. Genet. 1996, 58, 1101-1108.

130. Puck, J.M.; Willard, H.F. X Inactivation in Females with X-Linked Disease. N. Engl. J. Med. 1998, 338, 325-328. [CrossRef]

131. Orstavik, K.H. X chromosome inactivation in clinical practice. Qual. Life Res. 2009, 126, 363-373. [CrossRef]

132. Wu, H.; Luo, J.; Yu, H.; Rattner, A.; Mo, A.; Wang, Y.; Smallwood, P.M.; Erlanger, B.; Wheelan, S.J.; Nathans, J. Cellular Resolution Maps of X Chromosome Inactivation: Implications for Neural Development, Function, and Disease. Neuron $2014,81,103-119$. [CrossRef]

133. Gale, R.E.; Wheadon, H.; Linch, D.C. X-chromosome inactivation patterns using HPRT and PGK polymorphisms in haematologically normal and post-chemotherapy females. Br. J. Haematol. 1991, 79, 193-197. [CrossRef]

134. Fey, M.F.; Peter, H.J.; Hinds, H.L.; Zimmermann, A.; Liechti-Gallati, S.; Gerber, H.; Studer, H.; Tobler, A. Clonal analysis of human tumors with M27 beta, a highly informative polymorphic X chromosomal probe. J. Clin. Investig. 1992, 89, 1438-1444. [CrossRef]

135. Amos-Landgraf, J.; Cottle, A.; Plenge, R.M.; Friez, M.; Schwartz, C.E.; Longshore, J.; Willard, H.F. X Chromosome-Inactivation Patterns of 1,005 Phenotypically Unaffected Females. Am. J. Hum. Genet. 2006, 79, 493-499. [CrossRef]

136. Migeon, B.R. Why females are mosaics, x-chromosome inactivation, and sex differences in disease. Gend. Med. 2007, 4, 97-105 [CrossRef]

137. Bolduc, V.; Chagnon, P.; Provost, S.; Dubé, M.-P.; Belisle, C.; Gingras, M.; Mollica, L.; Busque, L. No evidence that skewing of X chromosome inactivation patterns is transmitted to offspring in humans. J. Clin. Investig. 2008, 118, 333-341. [CrossRef]

138. Shvetsova, E.; BIOS Consortium; Sofronova, A.; Monajemi, R.; Gagalova, K.; Draisma, H.; White, S.J.; Santen, G.W.E.; Lopes, S.M.C.D.S.; Heijmans, B.T.; et al. Skewed X-inactivation is common in the general female population. Eur. J. Hum. Genet. 2019, 27, 455-465. [CrossRef]

139. Cattanach, B.M.; Papworth, D. Controlling elements in the mouse: V. Linkage tests with X-linked genes. Genet. Res. 1981, 38, 57-70. [CrossRef]

140. Calaway, J.D.; Lenarcic, A.B.; Didion, J.P.; Wang, J.R.; Searle, J.B.; McMillan, L.; Valdar, W.; De Villena, F.P.-M. Genetic Architecture of Skewed X Inactivation in the Laboratory Mouse. PLoS Genet. 2013, 9, e1003853. [CrossRef]

141. Chadwick, L.H.; Pertz, L.M.; Broman, K.; Bartolomei, M.S.; Willard, H.F. Genetic Control of X Chromosome Inactivation in Mice: Definition of the Xce Candidate Interval. Genetics 2006, 173, 2103-2110. [CrossRef] [PubMed]

142. Simmler, M.-C.; Cattanach, B.M.; Rasberry, C.; Rougeulle, C.; Avner, P. Mapping the murine Xce locus with (CA)n repeats. Mamm. Genome 1993, 4, 523-530. [CrossRef] [PubMed]

143. Thorvaldsen, J.L.; Krapp, C.; Willard, H.F.; Bartolomei, M.S. Nonrandom X Chromosome Inactivation Is Influenced by Multiple Regions on the Murine X Chromosome. Genetics 2012, 192, 1095-1107. [CrossRef] [PubMed]

144. Galupa, R.; Heard, E. X-chromosome inactivation: New insights into cis and trans regulation. Curr. Opin. Genet. Dev. 2015, 31, 57-66. [CrossRef]

145. Sun, K.Y.; Oreper, D.; Schoenrock, S.A.; McMullan, R.; Giusti-Rodríguez, P.; Zhabotynsky, V.; Miller, D.R.; Tarantino, L.M.; de Villena, F.P.-M.; Valdar, W. Bayesian modeling of skewed X inactivation in genetically diverse mice identifies a novel Xce allele associated with copy number changes. BioRxiv 2021, 153, 1537-1551. [CrossRef]

146. Peeters, S.B.; Yang, C.; Brown, C.J. Have humans lost control: The elusive X-controlling element. Semin. Cell Dev. Biol. 2016, 56, 71-77. [CrossRef]

147. Morey, C.; Avner, P. Genetics and epigenetics of the X chromosome. Ann. N. Y. Acad. Sci. USA 2010, 1214, E18-E33. [CrossRef]

148. Veyver, I.B.V.D. Skewed X Inactivation in X-Linked Disorders. Semin. Reprod. Med. 2001, 19, 183-192. [CrossRef]

149. Schmidt, M.; Du Sart, D.; Kalitsis, P.; Fraser, N.; Leversha, M.; Voullaire, L.; Foster, D.; Davies, J.; Hills, L.; Petrovic, V.; et al. X chromosome inactivation in fibroblasts of mentally retarded female carriers of the fragile site Xq27.3: Application of the probe M27 $\beta$ to evaluate $X$ inactivation status. Am. J. Med Genet. 1991, 38, 411-415. [CrossRef]

150. Ham, A.L.; Kumar, A.; Deeter, R.; Schanen, N.C. Does Genotype Predict Phenotype in Rett Syndrome? J. Child Neurol. 2005, 20, 768-778. [CrossRef]

151. Carrette, L.; Wang, C.-Y.; Wei, C.; Press, W.; Ma, W.; Kelleher, R.J.; Lee, J.T. A mixed modality approach towards Xi reactivation for Rett syndrome and other X-linked disorders. Proc. Natl. Acad. Sci. USA 2018, 115, E668-E675. [CrossRef]

152. McMahon, A.; Monk, M. X-chromosome activity in female mouse embryos heterozygous forPgk-1and Searle's translocation, T(X; 16) 16H. Genet. Res. 1983, 41, 69-83. [CrossRef]

153. Viggiano, E.; Ergoli, M.; Picillo, E.; Politano, L. Determining the role of skewed X-chromosome inactivation in developing muscle symptoms in carriers of Duchenne muscular dystrophy. Qual. Life Res. 2016, 135, 685-698. [CrossRef]

154. Mattei, M.-G.; Mattei, J.F.; Ayme, S.; Giraud, F. X-Autosome translocations: Cytogenetic characteristics and their consequences. Qual. Life Res. 1982, 61, 295-309. [CrossRef]

155. Mattei, M.-G.; Mattei, J.F.; Vidal, I.; Giraud, F. Structural anomalies of the X chromosome and inactivation center. Qual. Life Res. 1981, 56, 401-408. [CrossRef]

156. Smith, J.C. Lewis Wolpert (1929-2021). Development 2021, 148, dev199618. [CrossRef]

157. Bainbridge, D. The X in Sex: How the X Chromosome Controls Our Lives; Harvard University Press: Cambridge, MA, USA, 2003. 
158. Gomez, M.R.; Engel, A.G.; Dewald, G.; Peterson, H.A. Failure of inactivation of Duchenne dystrophy X-chromosome in one of female identical twins. Neurology 1977, 27, 537. [CrossRef]

159. Richards, C.S.; Watkins, S.C.; Hoffman, E.P.; Schneider, N.R.; Milsark, I.W.; Katz, K.S.; Cook, J.D.; Kunkel, L.M.; Cortada, J.M. Skewed X inactivation in a female MZ twin results in Duchenne muscular dystrophy. Am. J. Hum. Genet. 1990, 46, 672-681.

160. Lupski, J.R.; Garcia, C.A.; Zoghbi, H.Y.; Hoffman, E.; Fenwick, R.G. Discordance of muscular dystrophy in monozygotic female twins: Evidence supporting asymmetric splitting of the inner cell mass in a manifesting carrier of Duchenne dystrophy. Am. J. Med Genet. 1991, 40, 354-364. [CrossRef]

161. Talon, I.; Janiszewski, A.; Chappell, J.; Vanheer, L.; Pasque, V. Recent Advances in Understanding the Reversal of Gene Silencing During X Chromosome Reactivation. Front. Cell Dev. Biol. 2019, 7, 169. [CrossRef]

162. Chaligné, R.; Heard, E. X-chromosome inactivation in development and cancer. FEBS Lett. 2014, 588, 2514-2522. [CrossRef]

163. Panda, A.; Zylicz, J.J.; Pasque, V. New Insights Into X-Chromosome Reactivation during Reprogramming to Pluripotency. Cells 2020, 9, 2706. [CrossRef] [PubMed]

164. Katz, D.M.; Bird, A.; Coenraads, M.; Gray, S.J.; Menon, D.U.; Philpot, B.D.; Tarquinio, D.C. Rett Syndrome: Crossing the Threshold to Clinical Translation. Trends Neurosci. 2016, 39, 100-113. [CrossRef] [PubMed]

165. Przanowski, P.; Wasko, U.; Zheng, Z.; Yu, J.; Sherman, R.; Zhu, L.J.; McConnell, M.J.; Tushir-Singh, J.; Green, M.R.; Bhatnagar, S. Pharmacological reactivation of inactive X-linked Mecp2 in cerebral cortical neurons of living mice. Proc. Natl. Acad. Sci. USA 2018, 115, 7991-7996. [CrossRef]

166. Lee, H.-M.; Kuijer, M.B.; Blanes, N.R.; Clark, E.P.; Aita, M.; Arjona, L.G.; Kokot, A.; Sciaky, N.; Simon, J.M.; Bhatnagar, S.; et al. A small-molecule screen reveals novel modulators of MeCP2 and X-chromosome inactivation maintenance. J. Neurodev. Disord. 2020, 12, 1-11. [CrossRef] [PubMed] 